\title{
AWARENESS ON INDIAN CITATION INDEX AMONG INDIAN RESEARCHERS
}

\author{
S. Vijayalakshmi ${ }^{* 1}$ 《
}

${ }^{1}$ Ph. D Research Scholar, Department of Psychology, Christ University, Bangalore, India

DOI: https://doi.org/10.29121/granthaalayah.v8.i5.2020.74

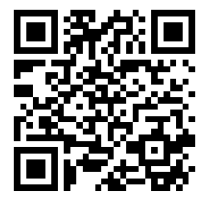

Article Type: Research Article

Article Citation: S. Vijayalakshmi. (2020). AWARENESS ON INDIAN CITATION INDEX AMONG INDIAN RESEARCHERS. International Journal of Research GRANTHAALAYAH, 8(5), 89-93. https://doi.org/10.29121/granthaa layah.v8.i5.2020.74

Received Date: 12 May 2020

Accepted Date: 28 May 2020

Keywords:

Indexing

Indian Citation Index

Indian Researchers

Survey

\begin{abstract}
Indexing is the quality parameter and reflection of the higher quality of the journal. Indexing is a process in which indexes are created in order to maintain the records so that the researchers can reach the requisite particular record easily. SCi, Scopus, Web of Science, Google Scholar, and Indian Citation Index are some indexing agencies. Among this Indian Citation Index is functioning from India, it is a new web platform for measuring performance of Indian research periodically. Most of the researchers aim and dream is to publish their work in recognised and quality journal, in this regard to quality of indexing Indian citation Index play vital role in the context of Indian research. The awareness on Scopus, Google scholar are more predominate among scholars whereas the awareness Indian Citation Index is to be studied, Hence, the author chosen the awareness on Indian Citation Index among Indian researchers to study by following survey method. This paper discusses the aspects of awareness among Indian researchers.
\end{abstract}

\section{INTRODUCTION}

\subsection{BACK GROUND OF THE STUDY}

Indexing generally referred as a tool to measure something or some indicator, it is mainly used in financial market as a statistical measure for tracking economic data. Index derived from the Latin word "Indicare" means "to point out'. According to International Organization of Standardization (ISO) 999, 1996, defines an index as an alphabetically or otherwise ordered arrangement of entries, different from the order of the document or collection indexed, designed to enable users to locate information in a document or specific documents in a collection.

Indexing is the process of providing access to the information. According to Borko and Bernier (1978) indexing is "the process of analyzing the informational content of records of knowledge and expressing the informational content in the language of the indexing system". Indexing is the process of producing an index and an index is the product of an indexing process. The process can be done by humans, by computer programs or by combinations.

Indexing is quality parameter and reflection of the higher quality of the journal. Indexing is a process in which indexes are created in order to maintain the records so that the researchers can reach the requisite particular record easily. The Science Citation Index (SCI) was first promulgated in Science in 1955, as an up-to-date tool to facilitate the dissemination and retrieval of scientific literature Garfield, (1955).

(C) 2020 The Author(s). This is an open access article distributed under the terms of the Creative Commons Attribution License, which permits unrestricted use, distribution, and reproduction in any medium, provided the original author and source are credited. 
All the researchers must ware of the indexing process and the area connected with indexing because indexing the quality factor of the journal. Most of the researchers aim and dream is to publish their work in recognised and quality journal, In this regard to quality of indexing Indian citation Index play vital role in the context of Indian research. The awareness on Scopus, Google scholar are more predominate among scholars whereas the awareness Indian Citation Index is to be studied, Hence the author chosen the awareness on Indian Citation Index among Indian researchers to study.

\subsection{MAJOR CITATION INDEXING SERVICES ARE}

SCI: Published by ISI a part of Thomson Reuters. SCI was originally produced by ISI and created by Eugene Garfield.

Scopus: Scopus (Elsevier) is a bibliographic database containing abstracts and citations for academic journal articles.

Indian citation index (ICI): An online citation data ICI is a new web platform for measuring performance of Indian research periodically. This online bibliographic database was launched in 2009.

In addition, Crossref, Chemical Abstracts Service, Biological Abstracts, BIOSIS, MIAR, ABDC, Index Copernicus, Bielefeld Academic Search Engine, CiteSeer, Google Scholar and etc are some of the indexing. All these popular indexing agencies have their own policies regarding indexing a journals. To ensure the quality of the agencies, they always consider including and indexing better quality journals.

\subsection{NEED OF INDEXING}

1) Provide easy and quick access to information from collection of data

2) Maximum storage and recall of relevant information

3) Quick to locate the required data

4) Save time and effort of the searchers

5) Identify the relevant information

6) Group together related topics

\subsection{INDIAN CITATION INDEX}

Indian Citation Index (ICI) is a home-grown abstracts and citation database, with multidisciplinary objective information or knowledge contents from about 1000 top Indian scholarly journals. ICI database is an abstracts and citation database intended to measure and perform two basic functions, general literature search and evaluation using citations similar to international databases. A database in general is a collection of information that is organized so that it can easily be accessed for various purposes, managed, and updated regularly.

Indian Citation Index (ICI) is developed by "The Knowledge Foundation" a registered society. It is one of the pioneers in India to develop, preserve, disseminate and serve customized knowledge products and services to scholarly world. Currently, it is publishing approximately about 170 journals from India with one of the specific motives to promote knowledge contents published in local national journals and bridge the gap between the content sources and content users via World Wide Web. It contributes to the various domains of and available with online full text. The ICI database enables access and empowers users to search, track, measure and collaborate in the sciences, social sciences, arts, and humanities to turns raw data/information into the powerful knowledge one needs. ICI like other indexes enables user to move back in time to previously published papers, but uniquely one can also look forward in time to determine who has subsequently cited an earlier piece of research. This feature makes this database a specialized information product and highly useful for researchers, policy makers, decision takers, editors, librarians etc. http://www.indiancitationindex.com/ici.aspx?target=aboutus

\subsection{OBJECTIVE OF ICI}

1) To ensure access to articles published in local Indian R\&D literature at national and global level 
2) To reflect and represent true picture of locally published Indian Scholarly contribution at national and global level

3) To have an authentic tool or ground for effective and rigorous evaluation of Indian scholarly works.

4) Source: http://www.indiancitationindex.com/publisher.aspx

5) Aim of the Study

6) The aim of this study is to find the awareness on Indian Citation Index among Indian researchers.

\section{METHODOLOGY}

Quantitative survey method was followed in this study. The data were collected by using Google form.

The aim of the study is find awareness on Indian Citation index among Indian researchers. To study the awareness, questions were framed based on the objective, motto, and other elements of ICI. The framed questions are filled in Google form and circulated among Indian researchers via mail and WhatsApp. 59 data were collected from researchers. The collected response is analysed for attaining the aim of the study.

\subsection{NATURE OF THE SAMPLE}

The data were collected from 59 researchers. Both male and female researchers were taken part in this study among that 27 were male and 32 were female researchers.

Out of these researchers 20 researchers were not published article in indexed journal, 3 researchers were submitted their articles were accepted and awaiting for publication, and finally 36 researchers i.e $61 \%$ of sample in the this group have published in indexed journal. Hence it can be concluded that the sample know well about the indexing and indexed journal.

\section{RESULTS OF THE STUDY}

\subsection{INDIAN CITATION INDEX IS A SEARCH ENGINE}

Table 1: Response of Researchers - Indian Citation Index is a Search Engine

\begin{tabular}{|l|c|c|}
\hline Indian Citation Index is a search engine & $\mathrm{N}$ & Percentage \\
\hline Agree & 22 & 37.2 \\
\hline Disagree & 31 & 52.5 \\
\hline Do not know & 6 & 10.1 \\
\hline
\end{tabular}

From the table 1, it in evident that, 22 respondents aware that Indian Citation Index is a search engine, whereas 31 respondents do not agree ICI is a search engine and 6 respondents do not about the ICI is search engine. We can conclude that the component ICI is a search engine is not aware by about $52.5 \%$ of the researchers in this study. The graphical representation is presented in table 1 and figure 1

\section{ICl - Search Engine}

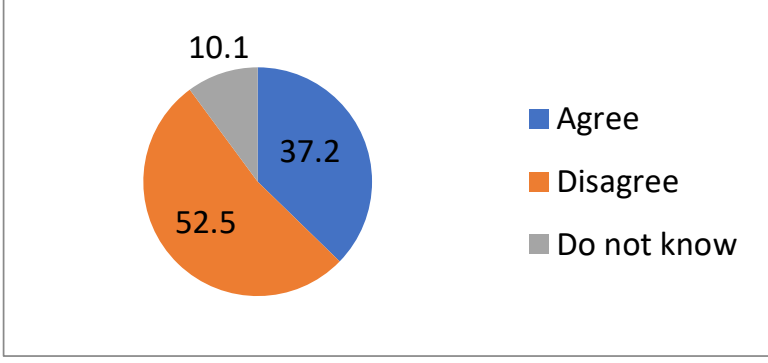

Figure 1: Response of Researchers - Indian Citation Index is a Search Engine 


\subsection{INDIAN CITATION INDEX PUBLISHES BOOK REVIEWS}

Table 2: Response of Researchers - Indian Citation Index publishes Book reviews

\begin{tabular}{|l|c|c|}
\hline Indian Citation Index publish Book reviews & $\mathrm{N}$ & Percentage \\
\hline Agree & 31 & 52.5 \\
\hline Disagree & 9 & 15.25 \\
\hline Do not know & 19 & 38.77 \\
\hline
\end{tabular}

From the table 2, it in evident that, $52.5 \%$ of the respondents agree that Indian citation Index publish book reviews, whereas $15.25 \%$ (9) respondents disagree with ICI publish book review and 19 respondents do not aware about the ICI publish book review.

Actually, the ICI does not publish book review. We can conclude that component of ICI publish review book is not aware by 19 (38.77\%) researchers in this study and 31 (52.5) respondent wrongly answered about it.

Indian Citation Index serves Worldwide

Table 3: Response of Researchers - Indian Citation Index serves world wide

\begin{tabular}{|l|c|c|}
\hline Indian Citation Index serves worldwide & $\mathrm{N}$ & Percentage \\
\hline Agree & 18 & 30.5 \\
\hline Disagree & 40 & 67.79 \\
\hline Do not know & 1 & 1.6 \\
\hline
\end{tabular}

From the table 3, it in evident that, $30.5 \%$ of the respondents agree that Indian citation Index serve worldwide, whereas $67.79 \%$ (40) respondents disagree that ICI serve worldwide and 1 respondent do not know about the ICI serve worldwide.

Actually, the ICI serves worldwide. We can conclude that component of ICI serve worldwide is not aware by $(67.79 \%)$ of the researchers in this study and 1 (1.6) respondent do not know about the ICI serve worldwide or not. The researchers might think that Indian Citation Index only serves to Indian country and not worldwide.

Indian Citation Index used for Literature review

Table 4: Response of Researchers - Indian Citation Index used for Literature review

\begin{tabular}{|l|l|l|}
\hline Indian Citation Index used for literature review & $\mathrm{N}$ & Percentage \\
\hline Agree & 52 & 88.1 \\
\hline Disagree & 7 & 11.8 \\
\hline Do not know & 0 & 0 \\
\hline
\end{tabular}

From the table 4, it in evident that, $88 \%$ of the respondents agree that Indian citation Index used for literature review purpose, $11.8 \%$ of the respondents disagree that ICI used for literature review and no respondent is answered for the option do not know. Hence it is concluded that researchers aware of the component that ICI used for literature review purpose.

\section{CONCLUSION AND DISCUSSION}

From this study it is evident that only the component ICI is used for literature review is aware by many of research scholars. The other element like ICI is search engine, is a multidisciplinary, it serves worldwide and ICI publishes book review are not much aware by the Indian researchers in this study. This shows awareness on Indian Citation Index is less among Indian researches. Universities can promote awareness on ICI among scholars and encourages them to publish in the journals indexed with ICI.

\section{SOURCES OF FUNDING}

None. 


\section{CONFLICT OF INTEREST}

None.

\section{ACKNOWLEDGMENT}

None.

\section{REFERENCES}

[1] Borko, Harold and Charles L. Bernier. 1978. Indexing Concepts and Methods. New York: Academic Press.

[2] Garfield E. (1955). Citation Indexes for Science: A new dimension in documentation through association of ideas. Science 122. 108-111.

[3] Garfield E. (2007). The evolution of the Science Citation Index. International Microbiology, 10. 65-69. DOI: $10.2436 / 20.1501 .01 .10$

[4] Indian Citation Index. http://www.indiancitationindex.com/ici.aspx

[5] http://www.indiancitationindex.com/publisher.aspx

[6] ISO 999:1996 Information and documentation-Guidelines for the content, organization and presentation of indexes. Geneva: International Organization for Standardization. 